\title{
Organizational Forms and Methods of Production Management Control
}

Fakhrutdinova L.R.

Kazan Federal University, Institute of Management, Economics and Finance, Kazan, 420008, Russia

Syradoev D.V.

Plekhanov Russian University of Economics (Kazan branch of the institute), Kazan, 420111, Russia

Terehova T.A.

Institute of social sciences and humanities, ), Kazan, 420111, Russia

Antonova N.V.

Kazan Federal University, Institute of Language, 420008, Kazan, Russia

\section{Doi:10.5901/mjss.2015.v6n3p727}

\section{Abstract}

The article offers methodological approaches to the management control system. The given work also identifies its place in control system on the basis of result-oriented method and differentiates between management control and operational control. On the other hand, the notion of system itself presupposes a need for monitoring and feedback to provide the system's livelihood. Control becomes a function which combines all the other management functions. In terms of consistency control is an indispensable mechanism to supervise the basic management process, consisting in making managerial decisions. The article estimates financial control over performance level.

Keywords: operational control, managerial control, strategic control, management by exception, scheduling techniques, plan, budget, profit control, system.

\section{Introduction}

In traditional management theory which describes management as a process consisting of a sequence of coherent and interconnected elements, control occupies one of the basic positions as an element which does not only finalize the process but also gives rise to new program decisions [1].

Managerial control, which is a pre-requisite for successful economic performance, receives its further development and practical progress in the current context by improving management accounting methods and computer-aided information processing, as well as employing analytical decision making techniques and system-oriented analysis [2, 3, 4].

According to American authors the so-called production supervision is usually combined with production planning and control and together they perform the common function of factory operation. Operational manufacturing supervision aims to fulfill the production plan [5]. In this light, supervising functions are described as an element of productive process. It includes scheduling, production control, bid control system and machine loading supervision.

\section{Methods}

The following practical methods, for example, are used for operational planning and control: Gantt chart, PERT system, critical path analysis.

In any sphere of industrial company's activity including manufacturing management, merchandising, finances, personnel etc., we can find both common and specific methods and control procedures. According to experts, "the same methods to spot the divergence and regulation measures can be employed for all elements of manufacturing systems, including work force, operation and production". 
In the meantime, however, different management levels require widely different access to the data. Hence, the methods used to solve operational control problems cannot be implemented for managerial control.

Principal investigators (P. Drucker, J. Dearden, R. Anthony, etc.) make a sharp difference between operational control (also called administrative or tactic control) and managerial (in other words, supervisory or strategic) control.

Differentiation between operational and supervisory or managerial control is basically a manifestation of separation between factory operation and strategic management and planning, accompanied by decentralization of the former and centralization of the latter.

In exercising managerial control functions the principles applied are those of "management by exception" and "management by objective". Activity-based accounting method implies a certain administrator's responsibility for certain types of expenditures and indexes. The method based on segregation of duties and responsibilities accounting is a "keystone of any management control system" [6].

As a result, business managers are permitted to focus their efforts on the basic problems and bottlenecks in order to eliminate them. The key figures are the factors which most affect the overall result and achievement of the objective set before the business unit under control.

Performance control of production departments and their managers is carried out on the basis of the resultoriented method, which consists in designing specific individually tailored targets and plans concerning various qualitative and quantitative indicators for each business unit and manager in accordance with their functions.

The already existing estimations demonstrate that by setting specific targets before sector team managers we can improve their efficiency. Encouraging managers to express their ideas for improvement is considered fundamental, since the responsibility for accomplishing the identified goals implies the right for self-selecting the way to achieve them $[7,8]$.

Decision control methods are based on the presumption that each production process or operation has certain "inputs" and "outputs", i.e. expenditures and results. Therefore to estimate the decision effectiveness we may compare the projected and actual "input" and "output" and the return resulting from the decision, i.e. the ratio of "output" to "input". For example, in comparing expected and actual expenditures, which is usually easier to fulfill, cost overrun indicates inefficiency of the decision made.

Managerial accounting system makes it possible to reveal the necessary data, which are normally included in customary accounts and records. It is collection of sufficient statistical data and creating well-grounded guidelines for managers that represents a challenge. It is necessary to consider various external and internal factors, including the effect of external conditions, decision complexity, managers' qualification, etc.

Implementation of consistency principle leads to substantial changes in traditional definition of essence and mechanism of control. One of the stages in exercising control is defined as identification of the predicted results from decision making process in terms of its efficiency. In case a wrong decision was made, there is an amendment mechanism for decision making procedure and possibly for its consequences [9].

Control becomes a system, which consists of four basic elements:

1) Norms determining output of controlled processes or subsystems (normative output);

2) Sensing device to obtain information of factual implementation of processes (sensor);

3) Mechanism to compare actual and predicted action and estimation (comparator);

4) Correcting instrument (corrector).

Control mechanism measures the system "output" and if there is any departure from accepted standards it transfers the information to the mechanism, which regulates the system "inputs", thus implementing feedback system and self-regulation principle (Figure 1).

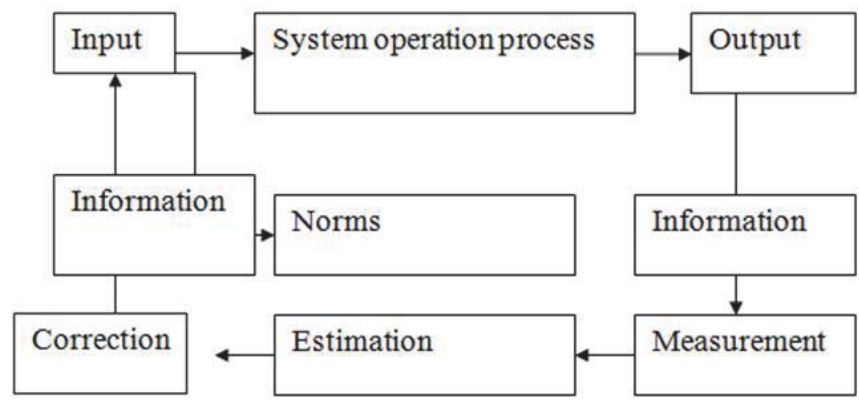

Figure 1. Elements of supervisory systems 
In systemic treatment of the management process the importance of control increases. The notion of system itself presupposes a need for control and feedback to provide the system vital activity. According to the big-name American scholars Murdick and J. Ross, "unlike the classical understanding of control as a process to force or "adjust the events to the plan", control in terms of cybernetics or systems, views the business or the subsystem as a "homeostatic machine with a self-regulation system", where control becomes a function, which consolidates the resting management functions".

In the context of consistency principles, control acts as an essential mechanism to monitor the implementation of management process, including making managerial decisions, performing management and coordination, as well as analyzing the process and searching for ways to improve it.

\section{Results}

The eventual outcome of production department activity being predominantly expressed in terms of monetary financial indicators, the total managerial control is largely based on fiscal control. Largely, but not only, since some pivotal quantitative aspects of activity may demand specific analysis and attention from managerial authorities. For example, fiscal accounting does not reflect utilization of labor resources, product quality, efficiency of scientific research and development, market inquiry, equipment handling, etc., as well as top executive management activity in the field of advanced planning and streamlining the intra-company managerial system (table 1).

Table 1. Basic financial indicators of enterprise activity

\begin{tabular}{|c|l|c|}
\hline № $\Pi / \Pi$ & Index & Sum of money thousand rubles. \\
\hline & Basic activity & 81000,0 \\
\hline 1 & Sales revenue & 36950,7 \\
\hline 2 & Cost of goods sold & 44049,3 \\
\hline 3 & Total profit & 4000,0 \\
\hline 4 & Business expenses & 8600,0 \\
\hline 5 & Management expenses & 31449,3 \\
\hline
\end{tabular}

Financial control is the basis of managerial control over production efficiency. Financial accounting which is usually organized as normative periodic forms, acts as the key instrument, used by the management team to assess the efficiency of expected performance. Using financial control system top management can affect the business activities of the units as well, which is a clear manifestation of the control centrality principle. In the meantime, however, in highly diversified modern group corporations whose fields of activities are so diverse, that the only common feature they share are financial relations, financial management is the key instrument of centralized control.

The company management team regularly approves basic financial scheme (responsibility center budgeting), which implies a particular level of income, profit, production costs and investments, and becomes a basis for comparing actual and target results. It is relevant information that emerges as the instrument of financial control.

Profit center operating principle is represented in figure 2.

There is a link between input and output.

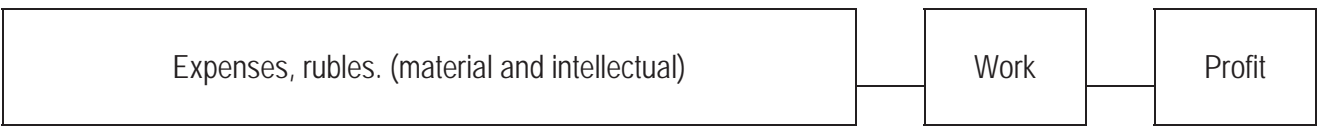

Figure 2. Profit center operating principle

Let us consider how control over profit can be exercised. The key objective of profitability index analysis is to provide a high income level to the fund-holders and glowing prospects for the company's future, as well as oversee the efficient use of resources. Profitability is treated from different perspectives: by industrial units, by types of products, by geographical areas. The index used for this purpose is the rate of return on investment and the profit/sales ratio. Both indexes are of paramount importance to business performance analysis.

For instance, improvement in profit margin indicates a more effective utilization of factory capacity. Changes in profit/sales ratio reflects possible fluctuations in prices, production cost value, as well as product mix alteration, including 
modification in the ratio between more or less profit-making products.

Profit margin can be expressed in terms of gross margin (gross profit), operating profit (so called operating income or taxable profit) and net profit. Gross profit equals to sales less product costs (cost of goods sold). Operating or taxable profit equals to gross margin less burden charges including overall, administrative and marketing expenses. Net profit equals to operating income less tax liabilities.

Use of all these values while computing profitability helps us reveal the impact of various types of production cost (both direct and indirect).

Profit margin is calculated relative to either working capital, i.e. circulating assets (current assets less current liabilities) and net fixed assets, or what is called net assets (i.e. net of borrowed proceeds). Such a calculation is also based on shareholder equity or investment capital, calculated from credit items (equity capital plus reinvested profit).

Therefore, while calculating earning power of real assets and return on investments we employ the so called accounting approach to appraise asset value, which recognizes them at book value. This method is commonly used for financial accounting and balance sheets, and is considered the most objective. There is another method, that of markedto-market economic appraisal, which reflects the real value of fixed assets and is used to make alternative managerial decisions on financing capital investments [10].

One of the most widely-spread estimate indicators in profit analysis is the rate of return on investment, which is counted through sequential calculation of the rate of capital turnover and profit relative to sales volume employing formula 1:

$\mathrm{ROI}=\underline{\mathrm{S}}$ * $\underline{\mathrm{P}}=\underline{\mathrm{P}}=\mathrm{TxR},(1)$

Where

$\mathrm{S}$ is the sales volume;

$\mathrm{P}$ is the profit (taxable or net);

$C$ is the shareholders' equity or net assets;

$T$ is the capital turnover;

$\mathrm{R}$ is the product (sales) profitability

The reduced calculation of return on investment offers a number of benefits against other methods to analyze profitability. This method makes it possible to identify the causes of changes, estimate the effect various factors have on the eventual outcome. For instance, capital turnover index reflects the efficiency of paid-in capital, stimulates improvement in material and technical supply, stocking up, distribution, stock reduction, improvement in equipment utilization, etc. The second element of the index reflects the profit share from sales of products and is largely dependent on production costs as well as market and distribution activities. A business or its production department can better the final figures by reducing costs and improving capital requirement [11].

A number of scholars assume the above-mentioned index to be the key performance indicator for production and profit-making activities. It is recommended by American Management Association (AMA) and is widely used in US industry (for example, by "DuPont", "Textron" and many others).

Apart from that, we should now pay attention to the developing concept of target prime cost management involving target costing system. Today one of the key success factors and competitive differentiators consists in innovative products. Manufacturers cannot any more sell huge standard lots very quickly, relying on steady markets, which compels managers to take new approaches to management (such as cost management). Japanese managers transformed the traditional price setting formula (formula 2) in target setting approach and expressed it as follows (formula 3):

Prime cost + Profit $=$ Price (2)

Price - Profit $=$ Prime cost (3)

This simple solution made it possible to obtain a preventive control and cost-cutting instrument as early as at the project phase.

\section{Conclusion}

From the foregoing information we might conclude that the existing supervisory systems are well-adapted to control production, distribution and other current operations, but they are not adjusted to control research development and introduction of new product lines, or plant development and familiarization with new manufacturing technologies. Hence, given the fact that these business activities take new shapes as project and matrix business administration methods, it is necessary to work out relevant planning and control techniques.

Therefore, profit is the most integral and at the same time, most synthetic performance index for industrial companies. Other indicators such as cost reduction, improvement of product quality, schedule performance, equipment 
utilization efficiency, etc. are estimated on the basis of their influence on profitability.

\section{References}

Gabdrakhmanov N.K., Rubtzov V.A., Shabalina S.A., Rozhko M.V.,. Kucheryavenko D.Z The role of territorial organization of cities in the touristic attraction of the region on the example of the Republic of Tatarstan // Life Science Journal 2014;11(11), Pages 451-455.

Denmukhametov, R.R. and O.V. Zjablova,. Geodemographic situation in the Republic of Tatarstan. World Applied Sciences Journal. Volume 30, Issue 11, 2014, Pages 1684-1688.

Gabdrakhmanov N.K. and M.V. Rozhko Positioning of Volga Federal District Regions by Demographic Situation Index // World Applied Sciences Journal, Volume 30 Number 6, 2014. - Pages 792-795.

Gabdrakhmanov, N.K. and V.A. Rubtsov, 2014. Tourist and Recreational Positioning of Tatarstan Republic: Cluster Analysis. World Applied Sciences Journal, 30(Management, Economics, Technology \& Tourism): Pages 202-205.

Gabdrakhmanov, N.K. and V.A. Rubtzov, 2014. Geodemographic Polarization Processes: Municipal Level (The Case of the Kukmorsky Municipal District of the Republic of Tatarstan). World Applied Sciences Journal, 30(10): Pages 1317-1320.

Bagautdinova, N., I. Gafurov, N., Kalenskaya and A. Novenkova, 2012. The regional development strategy based on territorial marketing (the case of Russia) World Applied Sciences Journal, 18. SPL.ISSUE., 18: Pages 179-184.

Mingaleva, Z., Bunakov, O. Innovative ways of using the tourist potential as the basis of territories development // Life Science Journal. Volume 11, Issue 6 SPEC. ISSUE, 2014, Pages 315-317.

Shen, W., Duenyas, I., Kapuscinski, R. Optimal pricing, production, and inventory for new product diffusion under supply constraints // Manufacturing and Service Operations Management, Volume 16, Issue 1, December 2014, Pages 28-45.

Lu, L.-C., Chang, W.-P., Chang, H.-H. Consumer attitudes toward blogger's sponsored recommendations and purchase intention: The effect of sponsorship type, product type, and brand awareness // Computers in Human Behavior, Volume 34, May 2014, Pages 258-266.

Donohoe, H. , Pennington-Gray, L., Omodior. O. Lyme disease: Current issues, implications, and recommendations for tourism management // Tourism Management, Volume 46, February 2015, Pages 408-418.

Helper, S., Henderson, R. Management practices, relational contracts, and the decline of general motors, Journal of Economic Perspectives Volume 28, Issue 1, December 2014, Pages 49-72. 